Вељко Ж. Брборић*

Универзитет у Београду

Филолошки факултет
UDC 37.014.5:811.163.41(497.11)

DOI https://doi.org/10.18485/fid.2018.8.ch4

\title{
СТАТУС СРПСКОГ ЈЕЗИКА У ОБРАЗОВНОМ СИСТЕМУ СРБИЈЕ ${ }^{1}$
}

\begin{abstract}
Сажетак
У раду се говори о месту и улози српског језика као наставног предмета у нашем систему образовања. Наиме, анализирамо заступљеност Српског језика (као наставног предмета) у постојећим наставним плановима и програмима, са кратким освртом на прошлост, али га и поредимо са неким земљама у Европи. Урадићемо кратак увид у број часова матерњег језика у нашем образовном систему, од основне школе до универзитета. Биће речи и о неким предлозима како да се статус Српског језика у образовном систему поправи. Ова тема је увек актуелна и мишљења су често подељена.
\end{abstract}

Кључне речи: српски језик, образовни систем, основна школа, средња школа, универзитет, наставни планови и програми.

\section{1. Увод}

Од устројства српског школства, пре нешто више од два века, у тада устаничкој Србији, Српски језик као наставни предмет, налазио се увек на првом месту у свим школским документима. То значи да је био најистакнутији и најзначајнији предмет у образовном систему. То се директно „видело” и у броју часова (недељном и годишњем) који су му били намењени. Истина, то није нека специфичност српског образовног система, тако је и у другим државама и у другим образовним

\footnotetext{
*3rboricv@eunet.rs

1 Рад је резултат рада на пројекту Срйски језик и њеїови ресурс: йеорија, ойис и иримена (бр. 178006), које финансира Министарство просвете, науке и технолошког развоја Републике Србије.
} 
системима - матерњи језик је неспоран и то није потребно посебно објашњавати. Ипак, образовање је код нас у деветнаестом и двадесетом веку претрпело доста измена, увођени су нови предмети, па је Српски језик (као наставни предмет) доживео озбиљно смањење када је у питању број часова на недељном и годишњем нивоу, и то у целокупном образовном систему. Место и улога једног предмета у настави и наставном процесу огледају се у његовом месту у званичним документима и увек се полази од званичног наставног плана и програма, односно од броја часова на годишњем нивоу, и то на свим нивоима образовања (основна школа, средња школа, универзитетска настава). Наравно, у приступу овом проблему често се могу наћи супротстављени ставови када је у питању укупан број часова (Брборић 2004, Брборић 2015, Брборић 2016). Тако се могу наћи „присталице” све три постојеће могућности: a) задржати постојеће стање, б) смањити број часова Српског језика и в) повећати број часова Српског језика. Први мисле да, када је посреди статус Српског језика, у образовном смислу ништа не треба мењати и да је постојеће стање добро. Овакво мишљење није нам блиско. Има и оних, чини се да су у мањини, који мисле да би се часови Српског језика могли смањити (жртвовати) и тиме појачати статус (број часова) неких других предмета, често су спомињани страни језици, али и неки нови (новоуведени) предмети. Ипак, чини се да су најбројнији они који мисле да је потребно повећати број часова матерњем језику. Овде предњаче људи из струке, али имају присталице и изван струке, без обзира на њихово образовање и професионално усмерење. За ову тезу често се наводе различити аргументи. Било је и оних који сматрају да је потребно одвојити наставу језика (граматике) од наставе књижевности. Тиме бисмо од једног добили два наставна предмета, али би се по мишљењу заговорника ове идеје настава језика (граматике) оснажила и постала обавезујућа, посебно у средњој школи.

\section{2. Статус матерњег језика у основној школи}

У Табели 1 дајемо број часова Српског језика у основној школи. Овај број часова није мењан више од 30 година и овде се јасно види број часова на годишњем и недељном нивоу, али и подела часова на 
три програмска подручја у оквиру нашег предмета (језик, књижевност и култура изражавања).

\begin{tabular}{|l|c|c|c|c|c|}
\hline & $\begin{array}{c}\text { недељно } \\
\text { часова }\end{array}$ & $\begin{array}{c}\text { годишње } \\
\text { часова }\end{array}$ & $\begin{array}{c}\text { настава } \\
\text { језика }\end{array}$ & $\begin{array}{c}\text { настава } \\
\text { књижевности }\end{array}$ & $\begin{array}{c}\text { култура } \\
\text { изражавања }\end{array}$ \\
\hline ПРВИ РАЗРЕД & 5 & 180 & 15 & 40 & 30 \\
\hline ДРУГИ РАЗРЕД & 5 & 180 & 40 & 80 & 60 \\
\hline ТРЕЋИ РАЗРЕД & 5 & 180 & 40 & 80 & 60 \\
\hline ЧЕТВРТИ РАЗРЕД & 5 & 180 & 45 & 80 & 55 \\
\hline ПЕТИ РАЗРЕД & 5 & 180 & 60 & 60 & 60 \\
\hline ШЕСТИ РАЗРЕД & 4 & 144 & 50 & 55 & 40 \\
\hline СЕДМИ РАЗРЕД & 4 & 144 & 50 & 55 & 35 \\
\hline ОСМИ РАЗРЕД & 4 & 136 & 45 & 55 & 36 \\
\hline
\end{tabular}

Табела 1: Часови Срӣской језика у основној школи

Табела 1 показује да је Српски језик од првог до петог разреда у званичном наставном плану и програму заступљен са по пет часова недељно, а од шестог до осмог разреда са по четири часа недељно. То истовремено значи да наши основци имају укупно 1.324 часа српског језика, односно око 165 часова на годишњем нивоу. Статистика показује да је настави језика (граматике) у основној школи намењено нешто више од четвртине - 345 часова (26\%), настави књижевности 505 часова (38\%), за наставу културе изражавања 376 часова (28\%), док 95 часова припада настави почетног читања и писања у првом разреду основне школе (7\%). По нашим сазнањима, настава језика (граматике) у основној школи се солидно реализује и часови језика се не „жртвују” у корист часова (наставе) књижевности. Ипак, вреди размислити да ли је овај однос добар и да ли су потребне неке мање корекције.

О статусу матерњег језика као фактору очувања идентитета пи-

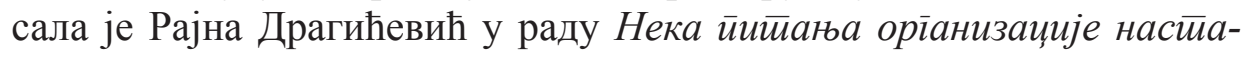

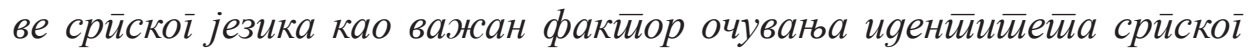
језика и куличуре (Драгићевић 2015). Ако направимо поређење између заступљености Српског језика у нашем образовном систему и заступљености матерњег језика у неким другим земљама, неће бити

2 У првом разреду скоро стотину часова припада обуци у почетном читању и писању, они нису назначени у табели и то може направити мању забуну. 
тешко закључити да видно заостајемо. Тако је, рецимо, матерњи језик у Француској од првог до петог разреда заступљен са 10 часова недељно, што је дупло више часова него код нас. Ово је податак који се не сме запоставити и ово је важно за сваку причу о статусу матерњег језика у образовном систему. У Турској је матерњи језик заступљен са по 10 часова у првом и другом разреду и са по 8 у трећем и четвртом разреду, па је просек 9 часова недељно. Затим, у Русији је матерњи језик заспупљен са по 9 часова у првом и другом разреду, 8 у трећем и 7 у четвртом разреду (просек 8,25 часова недељно). У Мађарској је у прва три разреда основне школе матерњи језик заступљен са по 8 часова недељно, а у четвртом разреду са 7 часова недељно (просек 7,75 часова недељно). Слични нама (5 часова недељно) су Украјинци и Белоруси, али вреди знати да је тамо, посебно у Белорусији, значај руског језика велики и настава је, условно речено, двопредметна - паралелно са матерњим језиком учи се и руски, што се сигурно одразило и на недељни број часова матерњег (белоруског/украјинског) језика у овим државама (Драгићевић 2015). Ако упоредимо ове податке са нашим, неће бити тешко закључити да озбиљно заостајемо по броју часова матерњег језика у млађим разредима основне школе и да се овај пропуст тешко може објаснити. Ово је посебно важно ако желимо говорити о првим знањима из матерњег језика у млађим разредима основне школе, знањима која стичемо од учитеља и која су посебно важна за наставак школовања. Средином деветнаестог века Српски језик је био заступљен са 10 часова недељно. Истина, тада је било мање предмета и наше школство је било организовано по европском моделу. После је број часова матерњег језика смањен, али се почетком двадесетог века добро држао и то са по 7 часова недељно. Тада је било и других предмета који су покривали његову предметност, као што је Лейо йисање (Краснойис). После Првог светског рата језик је преименован у српскохрватски, једно време се службено звао и српско-хрватско-словеначки, али је и даље недељни број часова био у просеку по 7 часова у млађим разредима основне школе (Стевановић 1977). И после Другог светског рата матерњи језик је имао пристојан, али и неуједначен број часова. Често су се мењали наставни предмети, а млађи разреди гимназије су постали старији разреди основне школе. У једном тренутку је чак матерњем језику, у млађим разре- 
дима, припадало и по 8 часова недељно, да би крајем шесте деценије двадесетог века недељни фонд био озбиљно смањен. Тада је уследио прелазак са шестодневне радне недеље на петодневну, и то се директно одразило и на укупан број часова (Брборић 2017).

\section{3. Статус матерњег језика у средњој школи}

Настава Српског језика у нашим средњим школама подразумева понављање, утврђивање, проширивање, систематизовање свих језичких знања стечених у основној школи, али читање прилично захтевне лектире из наставе књижевности. ${ }^{3}$ Наравно, настава културе изражавања (усмена и писмена) није спорна и она се састоји у добром владању језичким стандардом, али и у читању дела различитих књижевних врста и увидом у свеколики литерарни потенцијал домаће и преводне књижевности. Сведоци смо, нарочито последње две-три деценије, да се настава граматике у средњој школи маргинализује, односно да се не реализује у складу са предвиђеним наставним планом и програмом, и да се настава књижевности, условно речено фаворизује. Тако се часови језика (граматике) ,жртвују” за обраду књижевних дела. Истина, све чешће се говори и о кризи читања, па се с правом поставља питање шта се ради на часовима, ако ученици књижевна дела не читају, а избегава се реализација часова граматике. У српским гимназијама највише часова Српског језика има на друштвено-језичком смеру, а најмање на природно-математичком смеру. Заправо, на општем смеру српских гимназија (Табела 2) Српски језик је заступљен са по 4 часа недељно у сва четири разреда гимназије, док је у гимназијама друштвено-језичког смера у првом и другом разреду по 4 часа, а у трећем и четвртом разреду по 5 часова недељно. У гимназијама природно-математичког смера ситуација је следећа: први разред - 4 часа, други разред - 3 часа, трећи разред - 3 часа и четврти разред -4 часа. Овде је на четворогодишњем нивоу приметна осетна разлика између

3 Број часова нашег предмета у основној школи и средњим школама у нескладу је са програмом који ваља савладати по годинама. Ово се посебно односи на наставу књижевности. 
различитих типова гимназија. Тако се само у трећем разреду гимназије друштвено-језичког смера има више 70 часова Српског језика у односу на исти разред гимназије природно-математичког смера, док је та разлика на четворогодишњем нивоу око 150 часова, што није мали број. У Табели 2 дати су укупни часови Српског језика за гимназију општег смера и њихова дистрибуција на наставу језика, наставу књижевности и наставу културе изражавања. ${ }^{4}$

\begin{tabular}{|l|c|c|c|c|c|}
\hline & $\begin{array}{c}\text { недељно } \\
\text { часова }\end{array}$ & $\begin{array}{c}\text { годишње } \\
\text { часова }\end{array}$ & $\begin{array}{c}\text { настава } \\
\text { језика }\end{array}$ & $\begin{array}{c}\text { настава } \\
\text { књижевности }\end{array}$ & $\begin{array}{c}\text { култура } \\
\text { изражавања }\end{array}$ \\
\hline ПРВИ РАЗРЕД & 4 & 140 & 32 & 88 & 20 \\
\hline ДРУГИ РАЗРЕД & 4 & 148 & 30 & 91 & 27 \\
\hline ТРЕЋИ РАЗРЕД & 4 & 144 & 34 & 90 & 20 \\
\hline ЧЕТВРТИ РАЗРЕД & 4 & 128 & 30 & 80 & 18 \\
\hline
\end{tabular}

Табела 2: Часови Срйскої језика у среgњој школи (іимназија - оимшиии ииий)

Чини се да је настава Српског језика посебно угрожена у четворогодишњим стручним школама. Наиме, тамо је Српски језик заступљен са три часа недељно, захтеван је наставни програм из књижевности, па то додатно утиче да се настава језика (граматике и правописа) додатно маргинализује. Овде је, последњих година, било и неких, по нама, непотребних експеримената. Тако је у неким стручним школама са увођењем нових предмета и потребом учења више страних језика помињана и могућност додатног смањења броја часова Српског језика у основној школи и средњим школама. Такав случај забележен је у неким средњим медицинским школама и то су просветне власти правдале експерименталним радом. Томе су се одлучно супротстављале неке институције. Тако је Друштво за српски језик и књижевност Србије било принуђено да пре извесног времена упути отворени апел, како би се заштитио статус Српског језика у школском

4 Овде се нисмо бавили филолошким гимназијама и филолошким одељењима наших гимназија. Наиме, њихов број није велики и тамо је настава језика одвојена од наставе књижевности - то су два засебна предмета. У њима настава Српског језика има добар статус и то излази из домена овог рада. 
систему. ${ }^{5}$ Било је то после најаве да се у неким стручним школама недељни фонд часова Српског језика смањи са три на два часа (средње медицинске школе). Ипак, до смањења броја часова није дошло.

\section{4. Статус матерњег језика у универзитетској настави}

О статусу матерњег језика на универзитетском нивоу већ смо говорили неколико пута, а тиме су се бавили и други језички стручњаци (Брборић 2017). Статус матерњег језика на универзитетском нивоу представља посебну тему и он је, најблаже речено, посве неуједначен. На већини наших факултета нема садржаја из предметности матерњег језика, мада се код свих са академским образовањем подразумевају елементарна писменост и познавање основних граматичких и правописних правила. О статусу матерњег језика на универзитетима код нас прилично детаљно је писао Милош Ковачевић (Ковачевић 2012). Ковачевић је дао добар преглед статуса Српског језика на уни-

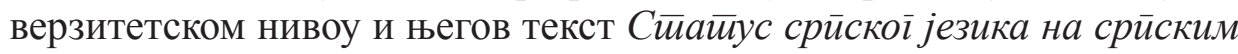
универзииееииима (Ковачевић 2012) би, по нашем суду, могао бити и програмски и обавезујући за овај ниво образовања.

Ипак, овде се мора направити одређена разлика. По нашем мишљењу, могли бисмо направити скалу која би имала пет различитих нивоа. Они би имали видну разлику, али би могли имати и један заједнички именитељ. На свим факултетима би се могло наћи места за једногодишње или једносеместралне курсеве из предметности матерњег

5 Апел је јасно тражио да се број часова не смањује ни на једном образовном нивоу. Посебно је било речи о неким средњим стручним школама, где је већ био смањен број часова или је смањење било у најави, али је апел јасно показао и образложио потребу да се број часова Српског језика повећа. Апел је упућен: Министарству просвете, науке и технолошког развоја Републике Србије, Одбору за образовање Народне скупштине Републике Србије, Национално-просветном савету Републике Србије, Савету за стручно образовање и образовање одраслих Републике Србије, Заводу за унапређивање образовања и васпитања, Заводу за вредновање квалитета образовања и васпитања, Филолошком факултету Универзитета у Београду, Филозофском факултету Универзитета у Новом Саду, Филозофском факултету Универзитета у Нишу, Филолошко-уметничком факултету Универзитета у Крагујевцу, Матици српској, Српској академији наука и уметности и Јавности. 
језика. Ево тих пет нивоа: Први ниво би били они филозофски и филолошки факултети на којима се изучава србистика. Такве факултете данас имамо у Београду, Новом Саду, Крагујевцу, Нишу, Приштини (седиште у Косовској Митровици) и Новом Пазару. ${ }^{6}$ Други ниво представљали би они факултети који школују будуће учитеље (наставнике разредне наставе) и они имају различите називе (учитељски и педагошки факултети). Неспорна је важност и улога учитеља у стицању првих знања из језика и књижевности у млађим разредима основне школе, будући да учитељске компетенције из предметности Српског језика имају невероватно важну улогу за даље образовање. Трећи ниво представљали би они факултети, тј. студијске групе, на којима се изучавају стране филологије (страни језици, књижевности и културе). Четврти ниво припадао би оним факултетима који припремају наставнички (професорски) кадар за рад у школама из свих наставних предмета изузев матерњег језика и страних језика (Ковачевић 2012). И на крају, као пети ниво, остају они факултети који спадају у категорију ненаставничких факултета. По нашем мишљењу, и овде има потребе и простора за наставу елементарних знања из матерњег језика, функционалне писмености и језичке културе.

Србистика се данас у Србији, како смо већ навели, изучава на шест универзитетских центара: Београд, Нови Сад, Ниш, Крагујевац, Нови Пазар $^{7}$ и Приштина (са привременим седиштем у Косовској Митровици). Вреди напоменути да је србистика у Црној Гори прилично маргинализована, мада се, условно речено, још држи у Никшићу. Србистика се у Републици Српској изучава на оба државна универзитета, тј. имамо националне катедре у Бањој Луци и Источном Сарајеву (Пале).

Увидом у наставне програме (курикулуме) није тешко утврдити и да је приступ настави Српског језика и на србистичким катедрама поприлично неуједначен, мада је неспорна претпоставка да сви србистички центри морају помало личити једни на друге. ${ }^{8}$

6 Сви назначени факултети су у државној својини и за сада немамо приватне факултете који спремају будуће стручњаке за матерњи (српски) језик. Истина, има факултета на којима се изучава предметност страних језика, литературе и културе.

7 Реч о Државном универзитету у Новом Пазару.

8 Данас се много говори о мобилности студената и ако бисмо претпоставили промену универзитета (факултета) на средини студија, видели бисмо озбиљне неприлике са којима би се могли сусрести наши академци. 
Нико не спори да факултети имају своју специфичност и да се ослањају на традицију, али је, по нашем мишљењу, превелика разлика и на оним факултетима на којима се изучава србистика. Као да су неки факултети сматрали да је њихова обавеза да се разликују од оног приступа који има факултет са најдужом традицијом - Филолошки факултет у Београду. Тако је на србистичким катедрама филолошких/ филозофских факултета у Крагујевцу, Бањој Луци и Источном Сарајеву, где су наставни планови и програми урађени као двопредметни и имају уједначен (равноправни) приступ настави српског језика и књижевности. Факултети са нешто дужом традицијом у Србији: Београд, Нови Сад, Ниш и Приштина имају по две групе (смера) - на једној има предност језик, а на другој књижевност. Овде се можемо упитати да ли је ово функционално, али јесте научно оправдано. Зна се да обе групе имају иста звања и ова подела се данас сматра наслеђеном, мада би се о оваквом приступу могло расправљати. ${ }^{9}$ У најмлађем, шестом лингвистичком центру у Србији на коме има србистике, оном у Новом Пазару, српска књижевност има предност над језичким дисциплинама, и он се у томе разликује од свих других филолошких/филозофских факултета на којима се изучавају националне дисциплине (Ковачевић 2012).

Сматрамо да разлике између наших србистичких центара нису оправдане и да бисмо првом приликом морали наћи више заједничког и више идентичних предмета, и по називима и по њиховом садржају. Разлика би се могла видети у приступу изборним предметима и курсевима. Ово је посебно видно уколико би студенти током студија хтели да промене факултет на коме студирају. ${ }^{10}$ Ово се у првом реду односи на основне студије, јер су студенти условљени да заврше ма-

9 Некада се, истина неформално, говорило да су студенти који су завршили студијску групу на којој су предност имали језички предмети „виђени” за основну школу, а они који су завршили студијску групу са више књижевности „Позванији” за средњу школу. Данас је ова теза изгубила актуелност и није предмет озбиљних разговора и оправданог приступа.

10 Овде би се ваљало присетити изворног болоњског процеса и приче о мобилности студента из различитих држава. Наши србистички центри оваквим приступом поприлично ограничавају мобилност студената између наших србистичких центара. Прелазак са једног факултета на други био би условљен полагањем великог броја различитих испита (предмета). То није за похвалу. 
стер студије, па ако су на једном факултету завршили студијску групу где је било више језичких предмета, а желе наставити мастер студије на другом факултету, појављују се непремостиви проблеми. Овде им је понекад избор ограничен и ми не разумемо овакав приступ. Таквих ограничења и проблема нема при упису на докторске студије.

Када су у питању два универзитетска центра у Републици Српској (Српско Сарајево и Бања Лука), тамо је однос језика и књижевности поприлично уједначен, тј. Српски језик и књижевност у наставним плановима и програмима имају равноправан статус и посреди је нека врста двопредметне наставе, као и у Крагујевцу (Ковачевић 2012). Оваква неуједначеност би се могла превазићи међуфакултетским и међукатедарским састанцима. Верујемо да ће их бити у скорој будућности и приликом процеса доакредитације који је обавезујући за све факултете. Међууниверзитески, тј. међукатедарски састанци би могли помоћи да се разлике смање и да мобилност студената буде реалност, у правом смислу те речи. Посебно би било добро да се овакав састанак одржи пре новог циклуса доакредитације основних, мастер и докторских студија наших србистичких центара.

И на учитељским (педагошким) факултетима који покривају српски језички и културни простор приступ настави Српског језика није уједначен. То се лако може видети увидом у њихове програме и називе курсева који се реализују на основним и мастер студијама. „Српски језик, без сумње, на овим факултетима нема статус какав би морао имати с обзиром на то какву и колику улогу имају садржаји српског језика у првим четирима разредима основне школе" (Ковачевић 2012: 19). У Републици Србији будуће учитеље данас образујемо у Београду, ${ }^{11}$ Сомбору (Универзитет у Новом Саду), Врању (Универзитет у Нишу), Лепосавићу (Универзитет у Приштини), Ужицу и Јагодини (Универзитет у Крагујевцу). Република Српска има два факултета: Педагошки факултет у Бијељини (Универзитет Источно Сарајево) и Учитељски факултет у Бањој Луци.

11 Учитељски факултет у Београду има два истурена одељења, једно у Вршцу, друго у Новом Пазару. Остаје нејасно због чега Државни универзитет у Новом Пазару нема учитељски (педагошки) факултет, већ то чини Универзитет у Београду, преко истуреног одељења Учитељског факултета. 
Посебан проблем представљају филозофски и филолошки факултети на којима се изучавају стране филологије. Ми тако школујемо будуће професоре страних језика који током студија немају ниједан предмет који се бави предметношћу матерњег језика. Овакав приступ сматрамо неодрживим. Овде би се прво морао увести Српски језик како обавезан наставни предмет, као једногодишњи (двосеместрални) предмет и уз то се може понудити неколико изборних из функционалне писмености, језичке културе и правописа српског језика. Ову тврдњу није потребно посебно образлагати. Овде је реч и о наставном и о научном приступу, па је тумачење Милоша Ковачевића неспорно: „При том се свјесно пренебрегава чињеница да филолози који се научно баве страним језиком своје најврједније, ако не и једино вриједне, резултате постижу контрастирањем српског језика са неким страним језиком, а за таква (типолошка или поредбена) истраживања познавање бар основа и специфичности структуре српског језика јесте нужан услов" (Ковачевић 2012: 20). ${ }^{12}$

Вреди рећи неколико речи и о нефилолошким факултетима који образују наставнике за друге премете. На тим факултетима нема Српског језика ни као основног ни као изборног предмета. Оправдано је да сви имају страни језик најчешће по избору, али је нејасно како Српског нема ни као изборног. „И кратким увидом у наставне програме наставничких нефилолошких факултета и ненаставничких факултета у целини можемо се запитати како се нашло места за различите предмете и курсеве који нису директно везани за одређену струку, а Српског језика, функционалне писмености и културе изражавања нема. Ово је питање о коме вреди разговарати и проблем који се мора решити. Можда би за почетак вредело кренути са изборним предметима на ненаставничким факултетима, док бисмо на наставничким нефилолошким факултетима одмах, без изузетка, могли увести предмет који би за предметност имао наставу српског језика" (Брборић 2017).

12 Није потребно посебно објашњавати у каквој су предности професори страних језика ако на часовима страни језик пореде са српским језиком и на таквим примерима ученицима објашњавају наставу граматике. С обзиром на то да је настава српког језика у средњим школама запостављена, неће бити добро ако се наставници страних језика ослоне само на знање српског језика стечено у основној школи. 
На овај проблем, тј. на место и улогу матерњег језика уопште, пажњу је скретао и академик Предраг Пипер, и то неколико пута. Посебно је говорио о месту и улози Српског језика и његовом статусу у образовном систему и друштву уопште. Тако је у раду Срйски језик између великих и малих језика ову причу свео на неколико тачака (Пипер 2016).

\section{5. Уместо закључка}

a) Број часова Српског језика у млађим разредима није задовољавајући, овде озбиљно заостајемо за већином развијених држава и сматрамо да су овде нужне корекције, тј. повећање недељног и годишњег броја часова.

б) Српски језик у старијим разредима основне школе не заостаје превише по броју часова, али би ваљало размислити о корекцијама и на овом нивоу образовања. Функционална писменост свршених основаца није на потребном нивоу. У основној школи заостајемо за европским просеком и његово повећање би било оправдано.

в) У нашим средњим школама статус Српског језика је неујдначен. У гимназијама би се морао појачати статус наставе граматике. Вредело би размислити и о увођењу изборних премета; ти предмети би могли имати различите садржаје. Остаје отворено питање да ли би се настава граматике могла одвојити од наставе књижевности. Када су у питању стручне школе, програм би се могао учинити мање захтевним и функционалнијим.

г) На филолошким (филозофским) факултетима на којима се изучава србистика настава Српског језика би се морала уједначити. Настава на учитељским факултетима би се морала додатно ојачати, док би се на студијама страних филологија и на факултетима који образују професоре за друге предмете Српски језик морао увести као обавезан предмет. Сматрамо да би било оправдано да се и на другим факултетима уведе предмет који би се бавио језичком културом. Истина, он би могао имати различите називе и различите програме у складу са потребама студената и њиховим будућим опредељењем. Не видимо зашто садржаји из предметности Српског језика не би могли бити изборни за све оне који стичу академско образовање. 
д) Вреди размислити и о томе да Српски језик у образовном систему добије натпредметни статус и тиме додатно ојача своје место и улогу у целокупном систему образовања (Драгићевић 2015).

\section{Референце:}

Брборић (2004): Брборић, В. Срӣски ӣравойис у насйавној ӣракси, Београд: Филолошки факултет.

Брборић (2015): Брборић, В. Правоиис и школа, Београд: Друштво за српски језик и књижевност Србије.

Брборић (2016): Брборић, В. О срйском йравойису, Београд: Друштво за српски језик и књижевност Србије.

Брборић (2017): Брборић, В., „Место и улога српског језика као наставног предмета у образовном систему”, Срисски језик и ћирилища gанас (Зборник радова), Вишеград: Андрићев институт.

Драгићевић (2015): Драгићевић, Р., „Нека питања организације наставе српског језика као важан фактор очувања идентитета српског језика и културе”, Узgанициа, год. ХІІ, бр. 1, Јагодина.

Ковачевић (2012): Ковачевић, М., „Статус српског језика на српским

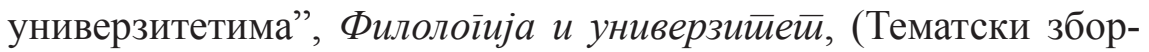
ник радова), Наука и савремени универзитет 1, Ниш: Филозофски факултет, 13-16.

Пипер (2016): Пипер, П., „Српски језик између великих и малих језика", Книжевности и језик, год. LXIII, бр. 1-2, Београд.

Станојчић, Поповић (2008): Станојчић, Ж. и Поповић, Љ. Грамайика срйскоі језика за иимназије и среgње школе, Београд: Завод за уџбенике (једанаесто издање).

Стевановић (1977): Стевановић, В. Насйавни йланови и йроіррами

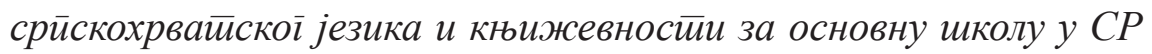
Србији, Београд: Републички завод за унапређивање васпитања и образовања. 


\section{Veljko Brborić}

\section{STATUS OF SERBIAN \\ IN THE EDUCATIONAL SYSTEM OF SERBIA}

\section{Summary}

The paper discusses the place and the role Serbian as a teaching subject in our educational system (primary, secondary and higher education). Namely, the presence of Serbian (as a subject) in the existing curricula is analyzed, with a brief overview of the past, but also in comparison with a number of European countries. A brief overview of the number of hourly classes per week of Serbian as the students' first language in our educational system is presented at all educational levels (from primary school to university). Suggestions for the imrpovement of the status of Serbian in our educational system are outlined, bearing in mind the fact that this topic is always current and that opinions vary significatnly among different interested parties.

Key words: Serbian as a first language, educational system, primary, secondary and higher education, university, language curriculum. 